\title{
Editorial
}

Dr. Susan Naomi Nordstrom, The University of Memphis, susan.nordstrom@gmail.com

\section{Makers-Philosophers-Researchers: Experimentations with (Dis)placements}

In 2017, a graduate class became something otherwise. It became an experimental place in which experiences poured through students rather than providing students ready-made experiences. It became a space to encourage the play of difference that challenge our ideas about race, class, gender, ability, sexuality, and so on as frictional events (Puar, 2012). It became a space in which students came to know themselves differently, even subjectify themselves in different ways through experience. By attending to the delicacies of social, material, aesthetic, cultural, historical, and disciplinary forces, the class became a generative space of producing knowledge differently, knowledge that changes us as it much as it changes disciplines (Manning, 2016). It became a space to write and do scholarship differently so as to stay close to the ground to attend to "the sensed social-material-aesthetic atmospherics resonant in a scene, the threshold onto worlds of expressivity in a problematics" (Berlant \& Stewart, 2019, p. 34). This Reconceptualizing Educational Research Methodology special issue offers five experimentations that materialized from such a course.

The course was a cross-disciplinary and cross-institutional collaboration between Memphis College of Art and University of Memphis (U.S.) in 2017. Led by myself and O. Gustavo Plascencia, then Associate Professor and Director of the MFA Programs at Memphis College of Art (now Assistant Professor of Art at University of Northern Texas), graduate students from both institutions explored how bodies are (dis)placed by intersections between poverty, available jobs with living wages, decent housing, quality education, and justice in Memphis, TN USA. The project was sponsored by the National Civil Rights Museum's commemoration of the $50^{\text {th }}$ anniversary of Dr. Martin Luther King JR's assassination and partially funded by an MLK 50 grant from the City of Memphis.

Throughout the project, we defined (dis)placed bodies as people and nonhuman bodies (e.g., sidewalks, trees, signs, buildings, and homes) that have been shifted by structural, economic, racial, sexual, and gender inequalities against their will. We used the term (dis)placed bodies to situate how structural inequalities are both embodied and real. We focused on an affirmative unity through (dis)placements to acknowledge injustice, create unity in troubled times, and work toward a justice to come.

By taking a cross-disciplinary and cross-institutional approach, we, too, became (dis)placed throughout the project. Throughout the co-taught course, we physically (dis)placed our routines as we met at both University of Memphis and Memphis College of Art. We spent class time walking neighborhoods as we engaged in walking methodologies (Springgay \& Truman, 2018). Plascencia and I then visited students at their home institutions meeting with individual students to support their final projects. We gave them 
few directions for the final project. We asked students to create a project (e.g., piece of art, paper, and so on) that reflected the conversations and collaborative work of the class as well as "data" collected during the walks. Students created their own definitions of "data" as they used visual methods (e.g., photograph and video), art, poetry, notes, and so on. Students were given one month to work on the projects. Following a gallery walk that displayed the students' work on the last night of class, Plascencia and I selected ten pieces that would be displayed at the Memphis College of Art's main gallery for a 2month exhibit.

Through, with, and against this class, we became untethered from our disciplinary boundaries that often limit thinking and creative responses to issues at hand. Class discussions, readings, and activities asked us to listen to other ways of doing art-making, philosophy, and research. We saw no division between art, philosophy, and research. Rather, we began to see ourselves as contingent and sometimes uneasy mixtures of all three disciplines.

We took a cue from Erin Manning (2012) who wrote that "to take the next step, is to move with the world" (p. 49) and Harrell Fletcher (2017) who noted that "it can change as we go along" (p.3). During the middle of the semester, we walked and moved with selected Memphis neighborhoods. Each step considered (dis)placements of ourselves and the people living and not living in those neighborhoods. Each step became part of the history of a neighborhood. Each step generated different thinking as they forced us to "become-with each other or not at all" (Haraway, 2016, p. 4) as we disrupted academic disciplinary boundaries. The walks drew us to stay together and to maintain unity as we walked toward something better.

Our staying together and unity are not practices of reducing everything to the same. Rather, these practices are grounded in difference. Everyone in the class came to it with different experiences and areas of expertise. As we listened and learned with each other, we began to see the richness of difference. There was no one way to walk, think, make, research, or philosophize. A central focus of the course was to enrich difference rather than reduce everything to the same. Staying together and unity here, then, is about staying together through difference and creating an uneasy and shifting unity.

This staying together is materialized in this special issue. Each student was invited to submit their work to the $\mathbf{2 0 1 8}$ International Congress of Qualitative Inquiry. That invitation generated two panels. From these panels, students were invited to submit to this special issue that uniquely features graduate students' learning about and engaging with arts-based research and philosophy. Although extant literature explores using art to teach students (Fleischmann \& Hutchison, 2012; Haidet et al., 2016; Jacobs, 2000; Rooney, 2004; Wade-Leuwen, 2016), no literature examines a class that integrates philosophy, art-making, and research as we did. The articles in this special issue showcase the assemblage - an assemblage rich with disciplinary, cultural, material, and aesthetic forces-generated by the class. 
Our class creatively experimented without method (Manning, 2016) in order to open up different ways of doing research. Benson's "Creating Outside the Box" describes her experiences with doing qualitative research differently and how those doings opened up different spaces for her as a researcher. She articulates and studies how these encounters that disrupted her thinking and sense of self. Wood's "Intentions and Repercussions of Revitalization: Urban Geographical Research Using Walking Methodology" details her process of merging art-making and research and how these two areas generatively fed each other in the production of knowledge about a Memphis neighborhood. Clevenger's “"Ask For a Miracle”: Memory, Manipulation, and Displacement in the Cooper-Young Neighborhood" examines how she used archival materials, visual methodologies, and walking methodologies to displace changes in a Memphis neighborhood. These displacing changes create a way to view the dominant and hidden narratives of the neighborhood. Bailey-Tarbett uses posthuman theories, archival materials, and walking methodology in her article, "Becoming Historic: A Postqualitative Look at One Memphis Neighborhood Association's Conceptualization of Preservation as "Activism." In her article, she describes how a neighborhood's process of gaining historic status was actually a veiled attempt of keeping certain bodies out of the neighborhood. In so doing, she argues that a neighborhood can never truly divorce itself from the socioeconomic and racialized city in which it is situated. Salem's contribution to the special issue, "(Un)settling methodology: Walking the City of Memphis with Transcorporeality in a More-then-Human World," takes three lines of flight that sprang forth from the walks. These lines informed her thinking on research methods with Muslim American youth, embodiment in space-time-mattering in a more-than-human world, and the idea of (dis)placed bodies functions within and against postcolonial theories. The authors and I would like to extend our gratitude to the reviewers of this special issue (all graduate students from a variety of institutions across the United States) and Joe Dunn, Susan's graduate assistant, who helped with editing and manuscript preparation.

This special issue makes no grand claims of solving the inequalities that (dis)places so many Memphis community members. A special issue, a course, and so on are not going to do that very important work. Changes to structural inequalities will only do that work. We modestly offer our staying together, our connections, and our walking with.

Dr. Martin Luther King JR called for a "dangerous unselfishness" in his last speech in Memphis, Tennessee in 1968. Such an unselfishness is a way "to stay together and maintain unity" (1968/2018) in the face of injustices. It is our hope that our staying together in this project and sharing this work with you may very well work toward such unselfishness, a becoming-with each other. 


\section{References}

Berlant, L. \& Stewart, K. (2019). The hundreds. Durham, NC: Duke University Press. https://doi.org/10.1215/9781478003335

Fleischmann, K. \& Hutchison, C. (2012). Creative Exchange: An Evolving Model of Multidisciplinary Collaboration. Journal of Learning Design, 5(1), 23-31. https://doi.org/10.5204/jld.v5i1.92

Fletcher, H., Sampson, S., Steen, E., Steel, A., smith, C., Kalin, A. Kurtz, L., Asher, K. \& Christopher, V. (2008). "It can change as we go along": Social practice in the academy and the community. Art Journal 67(4), 92-112. https://doi.org/10.1080/00043249.2008.10791329

Haidet, P., Jarecke, J., Adams, N., Stuckey, H., Green, M., Shapiro, D., Teal, C., Wolpaw, D. (2016). A guiding framework to maximise the power of the arts in medical education: a systematic review and metasynthesis. Medical Education, 50(3), 320-331. https://doi.org/10.1111/medu.12925

Haraway, D. (2016). Staying With The Trouble: Making Kin in the Chthulucene. Durham NC: Duke University Press. https://doi.org/10.1215/9780822373780

Jacobs, V. (2000). What happens when the artistic world and a teacher's world meet? Paper presented at the Annual Meeting of the American Educational Research Association (New Orleans, LA, April 24-28, 2000).

King, M.L. JR. (2018). I've Been To the Mountaintop. Speech given on April 3, 1968. Available at http://kingencyclopedia.stanford.edu/encyclopedia/documentsentry/ive been to the mount aintop/

Manning, E. (2012). Relationscapes: Movement, art, philosophy. Durham, NC: Duke University Press.

Manning, E. (2016). The Minor Gesture. Durham, NC: Duke University Press.

Puar, J.K. (2012). "I would rather be a cyborg than a goddess": Becoming-intersectional in assemblage theory. philoSOPHIA, 2(1), 49-66. https://www.muse.jhu.edu/article/486621

Rooney, R. (2004). Arts-based teaching and learning: A review of the literature. Prepared for: VSA Arts. Washington, DC. Prepared by: WESTAT. https://www.kennedycenter.org/education/vsa/resources/vsaarts lit rev5-28.pdf.

Wade-Leuwen, B. (2016). Intercultural arts-based research inquiry: First marks of the reformer's brush. Australian Art Education, 37(2), 151-164. 